\title{
The Demon of Inflation in India
}

\author{
Dr Malini Pande \\ Head - Department of Management, Dr MGR University, Chennai, India
}

\begin{abstract}
Inflation occurs due to an imbalance between demand and supply of money and/or changes in production and distribution cost or increase in taxes on products. One of the most complex challenges of our present times is the problem of rising Inflation and balancing growth requirements of the economy with controlling inflation. As the Government and RBI starts grappling with some of the complex problem of inflation and rejuvenating economic growth we all hope that the spectacle of India's growth story will take off once again. Fiscal deficit and Economic Reforms- the twin issues deserve importance because they probably hold the key to revival of economic growth. Several economists have rightly identified the problem of inflation as supplyside - lack of reforms discouraging productive investment. Fiscal profligacy has fuelled inflation. If the government is looking for ways to create a sustainable future growth path for the economy tackling the menace of inflation should figure high on its priority list. In this paper the challenges of inflation in India, drivers to inflation, dilemmas for the policy makers have been explored and discussed, and remedies suggested.
\end{abstract}

Keywords: Economic growth, fiscal deficit, inflation, infrastructure, interest rates

\section{Introduction}

"In a trade-off between growth and moderate inflation, I would plump for growth." These are the words of Nobel prize-winning economist Joseph Stiglitz. Stiglitz won the economics Nobel in 2001 for his work on how information asymmetry distorts the market, along with George Akerlof and Michael Spence. Stiglitz has been studying market failure on an increasing global scale and suggesting corrective action, on the part of regulators and governments. Inflation is the process of increase in the general (average) price level of goods and services in the economy. It is often the outcome of too much money chasing too few goods. . Its effect can be felt by each and every person to at least some degree. Inflation occurs due to an imbalance between demand and supply of money, changes in production and distribution cost or increase in taxes on products. When economy experiences inflation, i.e. when the price level of goods and services rises, the value of currency reduces. This means now each unit of currency buys fewer goods and services and this has an adverse impact on the consumer. High prices of day-to-day goods make it difficult for consumers to afford even the basic commodities in life. One of the most complex challenges of our present times is the problem of rising Inflation and balancing growth requirements of the economy with controlling inflation.

\section{Inflation In India}

The inflation rate in India was recorded at 7.31 percent in June of 2014. Inflation Rate in India averaged 9.54 Percent from 2012 until 2014, reaching an all time high of 11.16 percent in November of 2013 and a record low of 7.31 Percent in June of 2014. Historically, the wholesale price index (WPI) has been the main measure of inflation in India. WPI inflation rose to a five-month high of 6.01 per cent in May 2014 from 5.20 per cent in the previous month mainly driven by higher prices of food items. In 2013, the Governor of Reserve Bank of India Raghuram Rajan had announced that the consumer price index is a better measure of inflation since it measures the direct impact of prices on the consumer. As the new government battles stubbornly high food inflation, the economic survey 2013-2014 predicted that the headline inflation would ease by year end, providing room to the RBI to cut interest rates. "Headline WPI (wholesale price index) inflation is expected to moderate by the end of 2014. However, risks to the outlook stems from possible sub-normal monsoon and higher crude oil prices (on account of the crisis in Iraq)" - Economic Survey 2013-14. As inflation eases, it is expected that the RBI would adopt a more accommodative stance and bring down interest rate. "The monetary management challenge will also be helped by fiscal consolidation and addressing of supply side constraints that exacerbate food inflation. All these factors, in tandem, are expected to create room for monetary easing later this fiscal year," it said. Talking about the challenges, the Survey said, the Meteorological Department has predicted below-normal rainfall at 93 per cent of the long period average with 70 per cent probability of an El Nino occurring. The odds of a drought are 60 per cent now, compared with 25 per cent in April, Skymet, a private forecaster said. Besides, the other most prominent risk (to price rise) is the impact on oil prices on account of the crisis in Iraq. Crude oil prices are hovering around USD 110 per barrel. Two-thirds of India's oil needs are met through imports. Iraq is the second-largest oil supplier after Saudi Arabia. The survey said inflation showed signs of receding with average wholesale price index (WPI) inflation falling to a three-year low of 5.98 per cent during 2013-14 compared to 7 and 9 per cent over the previous two years. 
Consumer price inflation, though higher than the WPI, has also exhibited signs of moderation with CPI (newseries) inflation declining from 10.21 per cent during 2013-14 to about 9.49 per cent in 2013-14, the survey said. Food inflation, however, remained stubbornly high during 2013-14, reaching a peak of 11.95 per cent in third quarter.

As the Government and RBI starts grappling with some of the complex and what seems to be the intractable problem of inflation and rejuvenating stalled economic growth we all hope that the spectacle of India's growth story will take off once again. Woven into the sub-text of this monumental task are two tasks that need urgent resolution. Fiscal deficit and Economic Reforms- the twin issues deserve importance because they probably hold the key to revival of economic growth. Several economists have rightly identified the problem of inflation as supply-side - lack of reforms discouraging productive investment. Fiscal profligacy has fuelled inflation. Without fundamental economic reforms - cutting fuel subsidies, fast-forwarding infrastructure projects and reducing the fiscal deficit - no amount of monetary policy tinkering will tame inflation or spur GDP growth.

Growth decelerated steadily from 8\% during the quarter ended June 2011 to less than 5\% in 2013-14. But, both wholesale price index (WPI) and consumer price index (CPI) inflation remained elevated for a long time. The economy will grow only if we invest well in advance. Government has been focusing on welfare programmes that redistribute wealth rather than create assets. Programmes such as the NREGA have put money in the hands of rural population and obviously this extra money was utilised to purchase more foods items. Without sufficient investment in programmes for food generation, procurement, storage and transportation, prices have spiralled at a constant pace. So, what is more crucial is the mix, rather than the level of growth. Since the credit crisis, the country's potential growth has been deteriorating with a high fiscal deficit and persistently high growth in rural wages, even as private and public investment has been declining. These have had a negative impact on prices and productivity. In the past, price levels measured by WPI and CPI-industrial workers usually tracked a similar trend. But over the last three years, a huge gap has opened up. Non-food CPI levels have also persistently been higher than WPI/non-food WPI. Indeed, the gap between nonfood manufactured WPI - which represents 55\% of overall WPI - and CPI has been extremely large. To the extent that the gap between price levels as measured by CPI and WPI/WPI-core has been persistent and rising, we believe that WPI/WPI-core inflation are not sufficient to assess inflation expectations.

\section{Drivers To Inflation}

Fiscal deficit, rural wage, private investment and crude oil prices are the primary drivers to inflation and will be important to track. On fiscal deficit, it is more important to track expenditure growth. The government has announced its intention to increase one-off revenues via divestment but reducing the deficit in such a manner is unlikely to help reduce inflation. Apart from less-productive fiscal spending, high rural wages have also been a key factor in persistently high inflation expectations. According to the labour bureau, overall rural wages and rural farm wages have continued to grow at 19\% year-on year as of August 2012. It will be hard to curb CPI inflation when wage growth is so strong for such a large proportion of the workforce, and is not matched by a productivity increase. Increase in private investment is critical to augment the supply side and boost productivity growth. Recent policy actions are indicating the government's determination to address the persistent decline in private investment. Initially government will try and expedite existing projects before there is any revival in greenfield projects. The National Investment Board (NIB) can help quicken the process of granting project approvals, especially for those stuck midway or brownfield projects. But considering the challenges related to the current investment cycle, it would only be a gradual recovery in infrastructure and industrial capacity creation. Crude oil remains the single biggest import for India. Net crude imports are 5.4\% of GDP and account for $52 \%$ of the country's trade deficit. Crude oil prices are high, and contribute to high inflation.

\section{Tackling The Menace Of Inflation}

It is believed by some policy makers that bringing down the interest rates will improve the supply-side and, therefore, inflation. We should understand that low interest rates are not enough to stimulate capital expenditure. Indeed, RBI has recently highlighted real interest rates, as measured by both WPI and CPI inflation, are still much lower than during 2004-07, when investment growth was extremely strong. Persistent negative real rates will slow down deposit growth, keeping the credit-deposit ratio and market rates elevated. Policy reforms that improve the regulatory environment, increase legal certainty, fast track project approvals and creating incentives to invest are more important. If the government does not initiate a simultaneous cut in its spending and rural wage growth, in the initial phase of pickup in capex before it augments capacity, it will add to aggregate demand and inflation pressures. One of the key reasons for slackening growth is the slowing investment rate. There are many reasons for the slowdown in private investment - stubborn inflation, structural barriers, policy uncertainty and high interest rates. Investment needs to be concentrated in two 
areas: infrastructure projects and manufacturing. The reason for this is that with a lack of investment in building either capacity to meet enhanced consumption levels, or lack of investment in building infrastructure to provide and deliver goods and services from producers to consumers efficiently, friction builds up in the economy and leads to inflationary pressures. The prolonged inflation over past three years is testimony to that fact. The crucial issue is funding the infrastructure investment which by its very nature is enormous, long gestation and delivers results after a long period of time.. The Planning Commission has estimated the bill to be around Rs 41 lakh crore during 2012-17. While the government is expected to pitch in with 50\% (assuming it can fork out so much money), private sources of funds will still have to stump up the balance Rs 20 lakh crore. The known sources of private financing, such as bank loans, capital markets (for both debt and equity), external commercial borrowings, foreign direct investment, alternative investment platforms (such as private equity), will not be able to meet this huge bill. The requirement looks even more daunting when you add the investment needed for increasing manufacturing capacity. If we look at infrastructure alone, the banking system provided $56 \%$ of total funding to infrastructure projects during the first three years of the Eleventh Plan. After providing this funding, banks have to face two stumbling blocks: an asset-liability mismatch, since banks typically source short-term liabilities while infrastructure assets are usually long term in nature, and prudential sectoral caps.

\section{Dilemma One}

The corporate bond market is not yet developed. However, there are two untapped sources which can provide the large amounts required and match the maturity profile - insurance and pension, which account for around $32 \%$ of household savings. Companies in both these segments are sitting on huge pool of money, which are long term in nature but are not invested in long-term projects. This represents the only sources of long-term financing in the country are unable to invest in projects that not only match the maturity profile of their liability portfolio but could provide decent returns as well. The reason behind this apparent coyness is the investment norms governing these two segments. For instance, the investment norms mandate that insurance companies cannot invest in bonds of private sector companies with a credit rating below "AA+ ". This immediately rules out all infrastructure projects, most of which are undertaken through special purpose vehicles, which do not have any cash flows to begin with and, therefore, are rated way below the mandated floor. Due to the inflexible nature of the investment norms, a majority of the funds get automatically invested in government bonds, which are perceived as the safest investment in the economy.

\section{Dilemma Two}

The recent inflationary spiral has seen the headline rate of inflation often cross the yield on government bonds. This shrinks real returns for investors, inducing them to move away from financial savings into physical assets like gold or property. The impact can be seen in the reduction of net financial savings of households: from $12.2 \%$ in 2009-10 to 7.8\% of GDP in 2011-12, according to the RBI's latest Annual Report. The objective of protecting long-term investments from capital erosion has actually ended up leaving investors with very low returns, compared with other asset classes. Therefore, at a time when investment and pension funds might be requested to step up to provide long-term funds for nation-building, the investment policy pursued by them might ensure a flight of funds to other assets, particularly physical assets. If the government is looking for ways to create a sustainable future growth path for the economy, these two moral dilemmas should figure high on its priority list if it wishes to tackle the menace of inflation.

\section{Conclusion}

Fiscal deficit and Economic Reforms- the twin issues deserve importance because they probably hold the key to revival of economic growth. Several economists have rightly identified the problem of inflation as supply-side - lack of reforms discouraging productive investment. Fiscal profligacy has fuelled inflation. Without fundamental economic reforms - cutting fuel subsidies, fast-forwarding infrastructure projects and reducing the fiscal deficit - no amount of monetary policy tinkering will tame inflation or spur GDP growth. The two untapped sources which can provide the large amounts required and match the maturity profile are insurance and pension, companies in both these segments are sitting on huge pool of money, which are long term in nature but are not invested in long-term projects. This represents the only sources of long-term financing in the country are unable to invest in projects that not only match the maturity profile of their liability portfolio but could provide decent returns as well. The reason behind this apparent coyness is the investment norms governing these two segments. This is the first dilemma. The second dilemma is that the objective of protecting long-term investments from capital erosion has actually ended up leaving investors with very low returns, compared with other asset classes. If the government is looking for ways to create a sustainable future growth path for the economy, these two moral dilemmas should figure high on its priority list if it wishes to tackle the menace of inflation.

\section{References}




\section{Books:}

[1]. Inflation and India's Economic Crisis - Vijendra Kasturi Ranga Varadaraja Rao

[2]. Inflationary Trends in India by Aparna Bhardwaj, Rajesh Kumar

[3]. Interest Rates and Inflation in India By: K. R. Gupta

[4]. Pricing and inflation in India - Pulapre Balakrishnan

[5]. Articles: http://firstbiz.firstpost.com/economy/decoding-rbi-rajans-inflation-dilemma-why-india-may-have-to-wait-longer-for-arate-cut-91919.html

[6]. http://in.reuters.com/article/2014/06/02/us-india-economy-rates idINKBN0ED26Z20140602

[7]. http://economictimes.indiatimes.com/definition/inflation

[8]. Understanding Inflation and Controlling It - Kaushik Basu, Chief Economic Adviser, Ministry of Finance, Government of India

[9]. C. Marks Professor - Department of Economics, Cornell University, Ithaca, New York http://www.ceicdata.com/sv/search_campaign.php?ui_lang=EN\&how_hear=110\&spage=11578\&gclid=CNS1i5exuMACFQKSjgo dbSoAhg\#page= page- 1

[10]. http://www.epw.in/special-articles/how-should-inflation-be-measured-india.html 